\title{
シミュレーションによる再帰反射特性の推定と 都市キャニオンの日射反射率評価 \\ ESTIMATION OF RETROREFLECTIVE CHARACTERISTICS BY SIMULATION AND EVALUATION OF SOLAR REFLECTANCE ON URBAN CANYON
}

\author{
井上 奈緒子*, 永 村一 雄** \\ Naoko INOUE and Kazuo EMURA
}

\begin{abstract}
In this paper, the effect of retroreflective materials reducing the absorption of solar radiation in urban area are evaluated. The directional characteristics of reflection from glass beads with retroreflective properties are clarified using numerical simulation. Solar reflectances on two-dimensional urban canyon, as various building wall reflective characteristics and canyon aspect ratio, are estimated. The results show that glass beads have unique retroreflective properties and the retroreflective properties increase solar reflectance on urban canyon effectively. The effect is different in solar incident angle and canyon aspect ratio.
\end{abstract}

keywords : Heat island,Directional reflective characteristics, Retroreflection, Simulation,Urban canyon, Solar refrection ヒートアイランド, 反射指向特性, 再帰反射, シミュレーション, 都市キャニオン, 日射反射

1 はじめに

近年、都市部でヒートアイランド現象が深刻化しており、平均気 温の上昇や冬日、熱帯夜の増加に有意な傾向 ${ }^{1)}$ がみられる。その原 因の一つに、都市に密集して建つ建物や舗装道路が、日射や長波放 射を吸収し、蓄えた熱を大気に放出することが挙げられる。建物へ

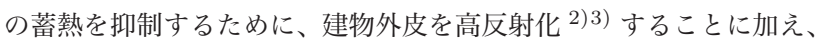
再帰反射性を利用して、日射を効率的に都市の天空に向けて反射さ せ、日射吸収量を減らすことが有効であると考えられる。

現在の再帰反射性の利用は、交通標識や路面表示など視認性向上 の目的 4)5) がほとんどである。そのため、再帰反射材料の反射性能 は、再帰反射方向への反射輝度指標を用いた「明るさ」の観点から の評価法 $\left.{ }^{6}\right)$ があるのみで、再帰反射方向以外の反射指向特性や「熱」 の観点からの評価法はいまだ定められていない。

建物外皮の反射指向特性と都市内部の熱放射環境の関係について は、従来から、反射指向特性の強い材料による照り返しが局所的な 表面温度の上昇をもたらすことで、周囲の温熱環境を悪化させる影 響が検討 7) されてきている。また、ガラス面に代表される鏡面反射 性の強い材料は、日射を都市内部にトラップするので、都市の日射 吸収量が増加すると考えられる。一方、再帰反射性は、周囲の建物 への反射日射を減らし、天空への反射日射を増やすことで、都市の 日射吸収量を抑制する効果が期待できる。日射反射における再帰反 射効果については、屋外測定による再帰反射材の日射に対する再帰 反射率の推定方法 $\left.{ }^{89} 9\right)$ や、複数の鏡面を用いて光を再帰反射させる ユニットを想定し、これを組み合わせたパネルの日射反射特性を推 定する数值計算方法 ${ }^{10)}$ が提案されている。

現在、一般に使用されている再帰反射材料は、その原理にガラス ビーズを用いたものとプリズム素子を用いたものに大別でき、建物 外皮のような大きな面積に施工する場合、道路区画線のようにガラ スビーズを塗料に混入して塗布する方法が想定される。

本研究では、対流を除いた熱放射環境のみに注目し、ガラスビーズ
の反射の方向分布をシミュレーションにより推定し、建物外皮に用 いられる再帰反射材料の反射指向特性をさぐる。また、単純な 2 次 元都市キャニオンを想定し、建物壁面の反射率と反射指向特性なら びにキャニオンの形状を変えて、キャニオン全体の日射反射につい てシミュレーションを行い、都市に再帰反射も加味した被覆を行っ たときの日射反射に与える影響を評価し、都市の温熱環境改善効果 を検討する。

2 シミュレーションによるガラスビーズ反射指向特性推定

2.1 光線追跡シミュレーションの概要

ガラスビーズの反射指向特性を探るため、ガラスビーズに入射し た光がガラス表面で屈折して (一部は反射する) ビーズ内部に入り、 ビーズ背面で反射され再びビーズの外に出射する過程を、モンテカ ル口法を用いた数值計算で模擬し、入射光線から見た反射光線のず れの角度とその分布を求める。シミュレーションでは、ガラスビー ズ 1 個が壁面 (垂直面)に半球分埋め込まれた状態を仮定しており、 反射の光跡の様子は図 1 となる。図中の記号を表 1 に示す。

計算の流れを図 2 に、計算の詳細を付録に示す。図 2 の $(1) \sim(6)$ において、ガラスビーズの屈折率 $n=1.93$ 、入射光の高度 $h=60$

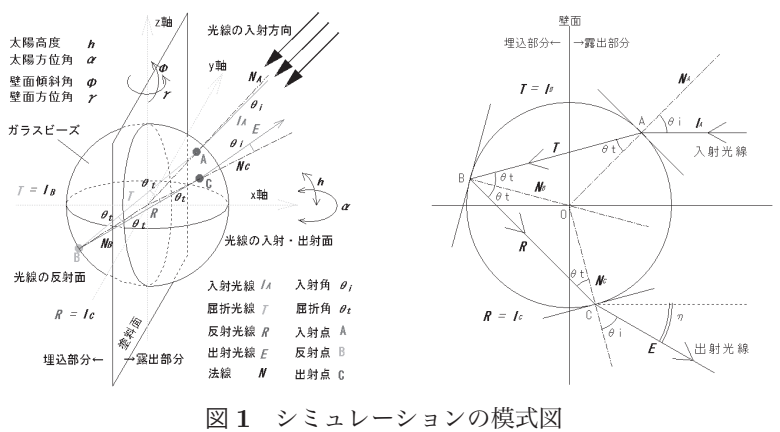

\footnotetext{
* (侏山武

(元 大阪市立大学生活科学部 学生)

$* *$ 大阪市立大学大学院生活科学研究科 教授 $\cdot$ 工博

Yamatake Corporation
Prof., Graduate School of Human Life Science, Osaka City Univ., Dr. Eng.
} 
表 1 図 1 および付録で用いる記号

\begin{tabular}{|c|c|}
\hline$n$ & :ガラスビーズの屈折率 [-] \\
\hline$r$ & :ビーズ (真球)の半径 \\
\hline$h$ & : 入射光線の高度 (太陽高度を想定) $[\mathrm{rad}]$ \\
\hline$\alpha$ & : 入射光線の方位角 (太陽方位角を想定) [rad] \\
\hline$\phi$ & :壁面の傾斜角 $[\mathrm{rad}] \quad(\phi=\pi / 2$ を仮定 $)$ \\
\hline$\gamma$ & :壁面の方位角 $[\mathrm{rad}] \quad(\gamma=0$ を仮定 $)$ \\
\hline $\boldsymbol{I}\left(x_{i}, y_{i}, z_{i}\right)$ & : 入射光線の向きを表す単位ベクトル 〈( ) 内は成分 〉 \\
\hline $\boldsymbol{T}\left(x_{t}, y_{t}, z_{t}\right)$ & : 屈折光線の向きを表す単位ベクトル 〈( ) 内は成分 $\rangle$ \\
\hline $\boldsymbol{R}\left(x_{r}, y_{r}, z_{r}\right)$ & : 反射光線の向きを表す単位ベクトル 〈( )内は成分〉 \\
\hline $\boldsymbol{E}\left(x_{e}, y_{e}, z_{e}\right)$ & : 出射光線の向きを表す単位ベクトル〈( ) 内は成分〉 \\
\hline $\mathbf{N}\left(x_{n}, y_{n}, z_{n}\right)$ & $\begin{aligned} \text { : } & \text { 単位法線ベクトル 〈( ) 内は成分 〉 } \\
& * \text { 入射側から屈折側に向かう向きを正とする }\end{aligned}$ \\
\hline$\theta_{i}$ & : 入射角 $[\mathrm{rad}]\left(0 \leq \theta_{i} \leq \pi / 2\right)$ \\
\hline$\theta_{t}$ & :屈折角 $[\mathrm{rad}]\left(0 \leq \theta_{t} \leq \pi / 2\right)$ \\
\hline $\mathrm{A}\left(a_{x}, a_{y}, a_{z}\right)$ & : 入射点 〈( ) 内は座標 〉 \\
\hline $\mathrm{B}\left(b_{x}, b_{y}, b_{y}\right)$ & : 反射点 $\langle($ ) 内は座標 $\rangle$ \\
\hline $\mathrm{C}\left(c_{x}, c_{y}, c_{z}\right)$ & : 出射点 $\langle($ ) 内は座標 $\rangle$ \\
\hline$\rho$ & :ビーズ表面での光の反射率 [-] \\
\hline$\tau$ & : ビーズ内部への光の透過率 [-] \\
\hline$l_{t}$ & : ビーズ内部で屈折光線が通過する距離 \\
\hline $\mathrm{R}$ & :一様乱数 \\
\hline$\eta$ & : 入射光線と出射光線のずれの角度 $[\mathrm{rad}]$ \\
\hline$\eta_{y}$ & : ずれの角度の方位角方向成分 [rad] \\
\hline$\eta_{z}$ & : ずれの角度の高度方向成分 [rad] \\
\hline$\theta_{e y}$ & :出射光線の方位角 [rad] \\
\hline$\theta_{e z}$ & :出射光線の高度 [rad] \\
\hline 添え字 & \\
\hline$A($ または $B, C)$ & : 入射点 $\mathrm{A}($ (たたは $\mathrm{B}, \mathrm{C})$ における、の意 \\
\hline
\end{tabular}

\begin{tabular}{|c|}
\hline (1) 壁面の方程式 \\
$\downarrow$ \\
(2) 入射点の決定 \\
$\downarrow$ \\
$\downarrow$ \\
(3) 入射点での表面反射 \\
$\downarrow$ \\
(4) 屈折光線の方向および屈折後の到達点 \\
$\downarrow$ \\
(5) 反射光線の方向および反射後の到達点 *1 \\
$\downarrow$ \\
(6) 出射光線の方向 \\
$\downarrow$ \\
(7) 入射光線と出射光線のずれの角度 \\
\hline
\end{tabular}

図 2 光線追跡シミュレーションの計算の流れ

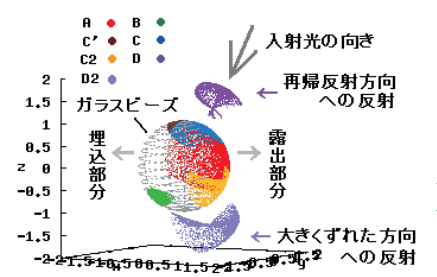

図 3 光線の入射・反射. 出射位置および出射方向

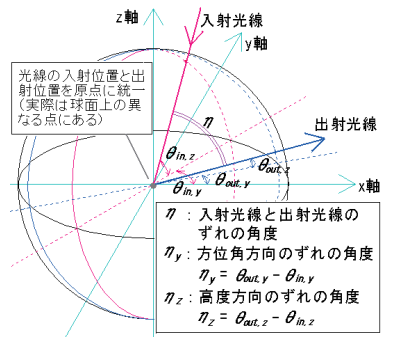

図 4 ずれの角度 $\left(\eta, \eta_{y}, \eta_{z}\right)$ $\left[^{\circ}\right.$ 、方位角 $\alpha=0\left[^{\circ}\right]$ としたときの計算結果を図 3 に示す。(7) の入 射と反射のずれの角度を求める幾何性状を図 4 に示す。

\section{2 ガラスビーズの反射指向特性の分析とモデル化}

ガラスビーズの反射指向特性は、その屈折率により異なる。また、 壁面に対する光の入射角 $i$ 注 1) が大きくなると、再帰反射方向およ びそれ以外の大きくずれた方向とに、強い反射分布をもつことが示 される。図 4 に示す入射光線と反射光線のずれの角度 $\eta$ と、その方 位角方向成分 $\eta_{y}$ および高度方向成分 $\eta_{z}$ について、先の計算により 求女た $1^{\circ}$ 間隔の度数分布を図 5 に示す。左列は高度 $h=20^{\circ}$ 、方位
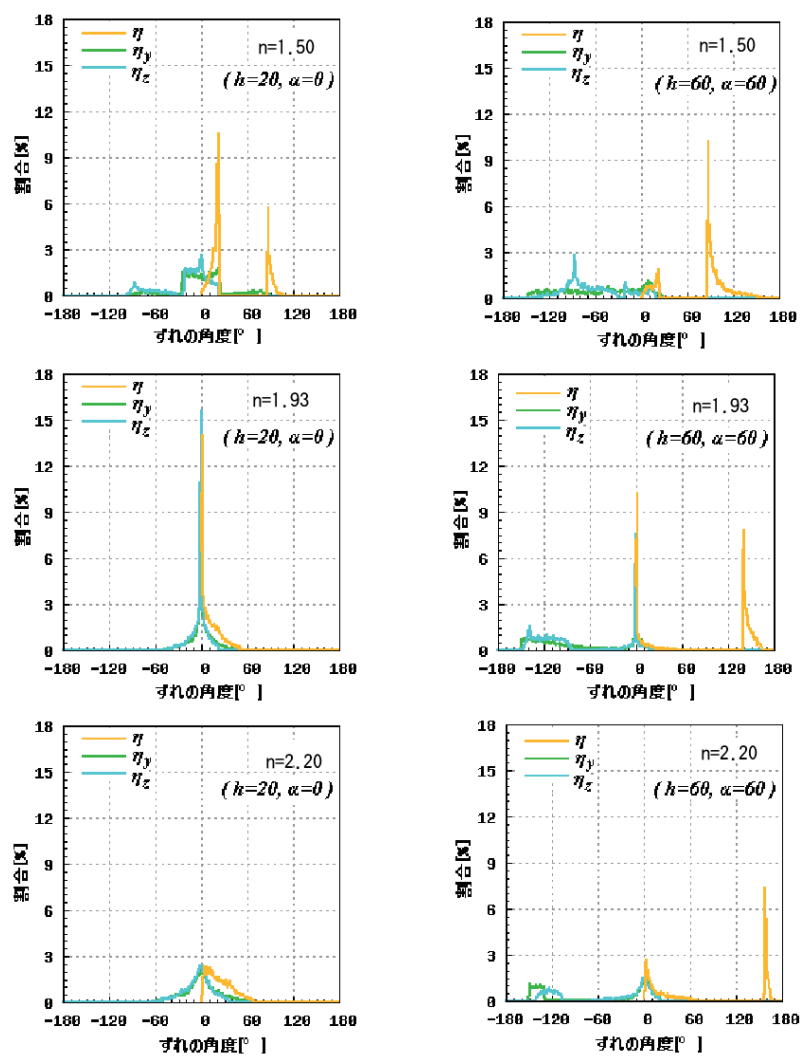

図 $5 \quad \eta, \eta_{y}, \eta_{z}$ の度数分布

表 2 1 つのデータファイルの既定条件

\begin{tabular}{c|c|l}
\hline ガラスビーズ & 屈折率 $n$ & $1.50 / 1.70 / 1.93 / 2.20 / 2.40$ \\
\hline \multirow{2}{*}{ 入射光 } & 高度 $h$ & $0^{\circ} \sim 85^{\circ}\left(0^{\circ} \sim 15^{\circ}\right.$ は $2.5^{\circ}$ 間隔、 $15^{\circ}$ \\
& & $\sim 60^{\circ}$ は $5^{\circ}$ 間隔、 $60^{\circ} \sim 90^{\circ}$ は $2.5^{\circ}$ 間 \\
& & 隔でデータを作成 $)$ \\
\cline { 2 - 3 } & 方位角 $\alpha$ & $0^{\circ} \sim 85^{\circ}\left(0^{\circ} \sim 15^{\circ}\right.$ は $2.5^{\circ}$ 間隔、 $15^{\circ}$ \\
& & $\sim 60^{\circ}$ は $5^{\circ}$ 間隔、 $60^{\circ} \sim 90^{\circ}$ は $2.5^{\circ}$ 間 \\
& & 隔でデータを作成 $)$ \\
\hline
\end{tabular}

角 $\alpha=0^{\circ}$ 、右列は $h=60^{\circ} 、 \alpha=60^{\circ}$ であり、屈折率 $n$ は上段か ら順に $1.50 、 1.93 、 2.20$ である。図 5 より、視認性の観点から最も 再帰反射性能が高いとされる屈折率 $n=1.93$ のとき、ずれの角度 $\eta \simeq 0^{\circ}$ の方向への反射が非常に大きく、西川 5) や井野 11) らの主張 を裏づける結果となった。また、屈折率が 1.93 から乘離すると反射 分布のばらつきは大きくなった。

視認性の観点でいう再帰反射性能は、「ずれの角度が \pm 1 ○の範囲 内になる反射の割合」で評価 ${ }^{5)}$ される。しかし、日射反射による熱 的効果では、ずれの角度が $\pm 1^{\circ}$ を越えても、その角度が小さければ 再帰反射とみなし、その比率で評価するのが実用的であろう。無論、 ずれの角度が $0^{\circ}$ 付近とみなす分布の幅については今後さらなる検討 が必要である。

シミュレーションの結果を用いて、入射光の高度および方位角と ガラスビーズの屈折率ごとに、反射指向特性を表現したデータベー スを作成した。デー夕の概要を表 2 、表 3 に示す。次章でこれを用 いてガラスビーズの反射特性の計算を行う手順を表 4 に示す。

\section{3 都市キャニオンの日射反射率推定}

\section{1 都市キャニオン空間とシミュレーションの概要}

図 6 に示す 2 次元都市キャニオン空間において、さまざまな都市 の形状 (アスペクト比 $=\mathrm{H} / \mathrm{D})$ と、建物壁面の反射率および反射指向 
表 3 1 つのデータファイルに含まれる項目

\begin{tabular}{|c|}
\hline 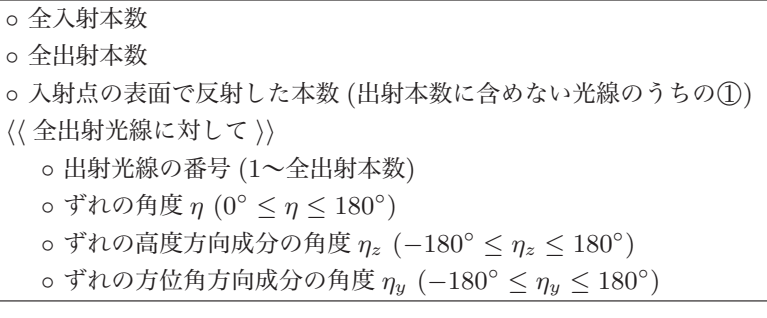 \\
\hline
\end{tabular}

表 4 ガラスビーズの反射特性を模擬する計算手順

\begin{tabular}{|c|}
\hline (1) 大射光の高度と方位角を算出 \\
$\downarrow$ \\
(2) ガラスビーズの屈折率および入射光の高度と方位角から、それに見 \\
合うデータファイル $* 1$ を決定 \\
$* 1$ 表 2 に示す間隔で作成したデータファイルのうち、最も值が近 \\
くかつ実際の高度と方位角の方が小さいものを抽出 \\
$\downarrow$ \\
(3) 全出射本数と入射点の表面で反射される光線の本数の割合から、乱 \\
数を用いて壁面での反射・吸収を決定 \\
$\downarrow$ \\
(4) 入射点の表面で反射される光線分は、拡散反射性を仮定 \\
$\downarrow$ \\
(5) (4)以外の出射光線分については、出射光線の番号をランダムに選出 \\
し、その番号の該当するずれの角度 (高度方向および方位角方向) に \\
より反射の向きを算出
\end{tabular}

表 5 計算の基本設定条件

\begin{tabular}{|c|c|}
\hline 計算日時 & $\begin{array}{r}6 \text { 月 } 21 \text { 日 (夏) } 5: 00 \sim 19: 00 \\
9 \text { 月 } 23 \text { 日 (秋) } 6: 00 \sim 17: 30 \\
12 \text { 月 } 21 \text { 日 (冬) } 7: 30 \sim 16: 30\end{array}$ \\
\hline 計算位置 & $\begin{array}{l}\text { 大阪 } \\
\left(\text { 北緯 } 34^{\circ} 35^{\prime} \cdot \text { 東経 } 135^{\circ} 30^{\prime}\right)\end{array}$ \\
\hline 天空状態 & 晴天空 $/$ 大気透過率 $=0.7$ \\
\hline 日射量 & $\begin{array}{l}\text { 法線直達日射量 : Bouguer の式 } \\
\text { 水平面天空日射量 : Berlage の式 }\end{array}$ \\
\hline 道路の軸方位 & $\begin{array}{l}\text { 東西道路 (南/北向き壁面) } \\
\text { 南北道路 (東/西向き壁面) }\end{array}$ \\
\hline 地表面 & $\begin{array}{l}\text { 反射率 }=0.2[-] \\
\text { 反射指向特性 : 拡散反射性 }\end{array}$ \\
\hline 光子の射出数 & $\begin{array}{l}10^{5} \text { 個 (ただし、ガラスビーズの反射指向特性モ } \\
\text { デルを用いる計算では計算負荷が過大になるた } \\
\text { め } 10^{4} \text { 個とした) }\end{array}$ \\
\hline 計算終了条件 & $\begin{array}{l}\text { 光子が天空面に向かう場合あるいは初期エネル } \\
\text { ギーに対して光子エネルギーが } 1 / 1000 \text { に減衰 } \\
\text { した場合 }\end{array}$ \\
\hline
\end{tabular}

特性 (拡散/鏡面/再帰/ガラスビーズ) を設定し、季節 $($ 夏/秋/冬) と 道路の向き (東西道路/南北道路) ごとに、モンテカルロ法を用いた 日射の反射計算を行う。

キャニオンに入射する日射は直達日射分と天空日射分を考慮し、地 表面の反射特性は固定した。計算の基本設定条件を表 5 に、計算の 流れを図 7 に示す。なお、拡散反射性を模擬する計算方法は成書 $\left.{ }^{12}\right)$ を参考にした。

\section{2 アスペクト比と日射反射率}

壁面の反射指向特性を拡散反射とし、アスペクト比と壁面反射率 を変化させて、キャニオン全体の日射反射率を計算した結果を図 8 に示す。また、湊ら 13) にならい、キャニオン各表面における入射日

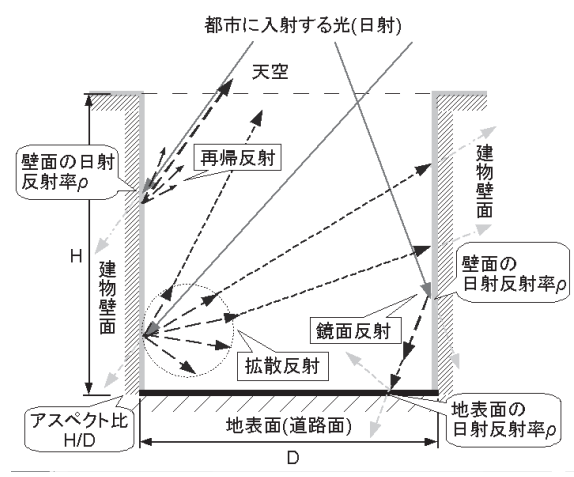

図 62 次元都市キャニオン空間の模式図

$$
\begin{aligned}
& \text { (1)天空と都市キャニオンの境界面に日射*が大射 } \\
& \text { * 直達日射々天空目射分讨て計算 } \\
& \checkmark \\
& \text { (2)日射がどの都市表面*1の、どの部分*2k入射するが学計算 } \\
& \text { *1 地表面もし〈は、2つの建物壁面(南向き·北向き / 東向き·西向き) } \\
& \text { *2 各都市表面を10個の部分に分けて、光の大射位置及び反射位置を決定している。 } \\
& \text { (3到達した点の反射性能より、どのような光の反射しくは }
\end{aligned}
$$

〈a. 地表面に大射〉

$$
\text { a-1)地表面の反射率より、反射し〈は吸收安決定 }
$$$$
\text { 〈反射〉 }
$$$$
\text { a-2)地表面の反射特性より、反射方向䒚決定 }
$$

b. 壁面に入射〉

b-1)壁面の反射率*より、反射し〈引吸收を決定吸收〉

$$
\text { 〈反射〉 }
$$

$\mathrm{b}-2)$ 壁面の反射特性*より、反射方向を決定

* ザラスビーズの反射特性を用いるときは

(4)該当点で吸収されだして 計算終つ

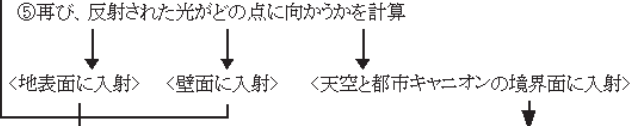
(6)都市全体から反射されたものとして、計算終了

(7)直達日射と天空日射の計算結果字合わせて。各都市表面*1の

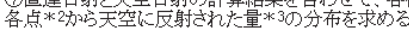

*1 地表面もし〈は、2つの建物壁面

*2 各表面ごとに10点 ＊3つまり、境界面に吸収された量

全ての大射光線し
犎て計算了紷了

図 7 計算の流れ

射量に対する日射吸収量の比の分布を求め、その事例を図 9 に示す。

（1）壁面が拡散反射性の場合、アスペクト比 $(0.25 \sim 4.0$ の範囲) が 大きいほど、日射反射率は低下する。

(2) 東西道路の夏以外では、アスペクト比が 2.0 と 4.0 の場合、日射 反射率の值に差がほとんどなくなる。

(3) アスペクト比が大きいほど、壁面反射率とキャニオン全体の日 射反射率の関係を表すグラフの勾配が大きくなる。壁面反射率 が高い方が、アスペクト比による日射反射率の差は小さい。

(4) キャニオン表面の日射吸収量の分布は、季節や道路の向き、ア スペクト比によって異なり、直達日射量が多い部分ほど分布が 大きくなる。

\section{3 壁面の反射特性と日射反射率}

キャニオンのアスペクト比を 1.0 とし、壁面の反射率と反射指向 特性を表 6 のように設定してキャニオン全体の日射反射率を比較し た結果を図 10 に示す。

(1) 南北道路では、季節を通じて日射反射率はほとんど変化しない。 

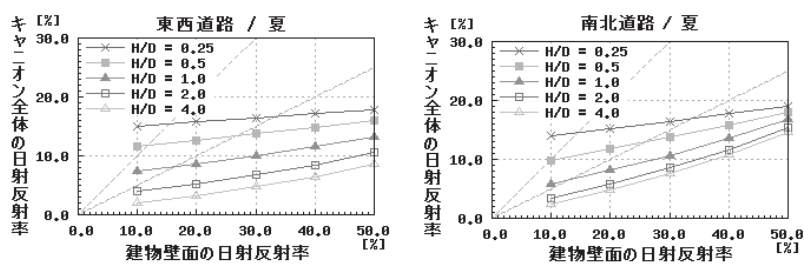

図 8 アスペクト比とキャニオン全体の日射反射率

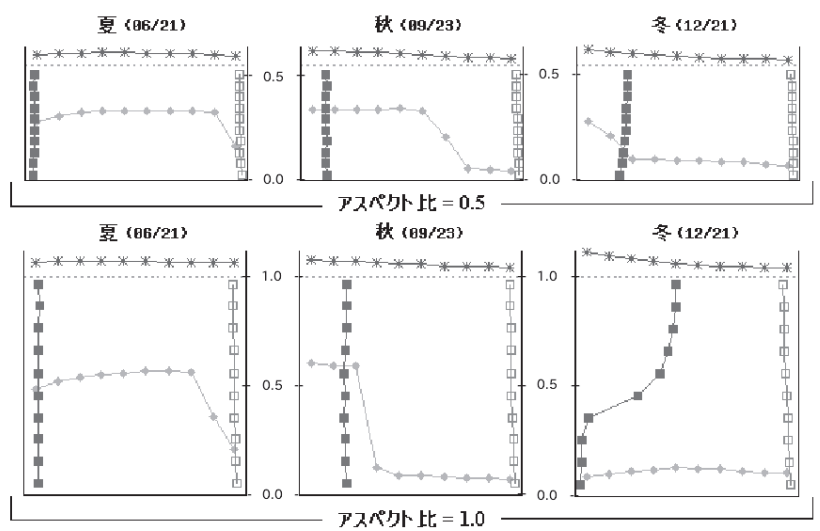

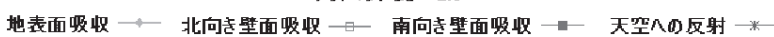

図 9 アスペクト比とキャニオン表面の日射吸収量分布

表 6 計算条件 (壁面の反射特性の条件)

\begin{tabular}{c|c|l}
\hline 記号 & 反射率 [- & 反射指向特性 \\
\hline \hline $\mathrm{A} 1$ & 0.2 & 拡散 $100 \%$ \\
\hline $\mathrm{B} 1$ & 0.2 & 拡散 $50 \%+$ 再㷌 $50 \%$ 注 2) \\
\hline $\mathrm{C} 1$ & 0.2 & 再帰 $100 \%$ \\
\hline $\mathrm{D} 1$ & 0.2 & 拡散 $50 \%+$ 鏡面 ${ }^{\text {注 } 3)} 50 \%$ \\
\hline $\mathrm{E} 1$ & 0.2 & 鏡面 $100 \%$ \\
\hline $\mathrm{A} 2$ & 0.5 & 拡散 $100 \%$ \\
\hline $\mathrm{B} 2$ & 0.5 & 拡散 $50 \%+$ 再㷌 $50 \%$ \\
\hline $\mathrm{C} 2$ & 0.5 & 再帰 $100 \%$ \\
\hline $\mathrm{D} 2$ & 0.5 & 拡散 $50 \%+$ 鏡面 $50 \%$ \\
\hline
\end{tabular}

一方、東西道路では、特に壁面反射率が高く、再帰反射性の強い 条件のとき、日射反射率は夏に低く、冬に高くなる傾向がある。 壁面反射率が低く、拡散反射性であるときは、東西道路でも季 節による日射反射率の変化はほとんどみられない。

（2）壁面を再帰反射性にしたり高反射化すると、キャニオン全体の 日射反射率は高くなり、日射の入射角が小さい東西道路の冬に その効果が最も大きく、入射角が大きい東西道路の夏には非常 に小さい。たとえば、壁面反射率 $50 \%$ の場合、「再帰 $100 \%$ は 「拡散 100\%」に比べて、東西道路の冬には約 $23 \%$ 、夏は約 $6 \%$ 、 南北道路では約 $16 \%$ 、日射反射率が高くなっている。

\section{4 アスペクト比と再帰反射効果}

壁面に再帰反射性を付与してキャニオン全体の日射反射率を高く する効果について、アスペクト比を変化させて比較を行う。計算条 件を表 7 に、計算結果を図 11 に示す。

（1）アスペクト比が大きいほど、再帰反射性によりキャニオン全体 の日射反射率を高くする効果が大きくなる。たとえば、南北道 路で、壁面反射率が $50 \%$ の場合、「拡散 50\%+再帰 50\%」は 「拡散 100\%」に比べて、アスペクト比が 0.5 のとき約 4\%、1.0
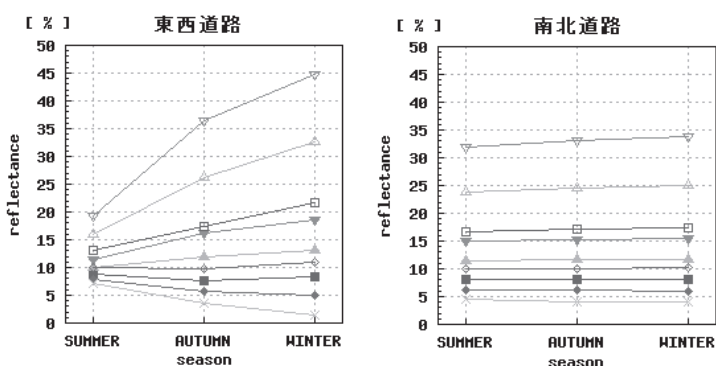

図 10 壁面の反射特性とキャニオン全体の日射反射率

表 7 計算条件 (壁面の反射率・反射指向特性およびアスぺ クト比 $(\mathrm{H} / \mathrm{D})$ の条件)

\begin{tabular}{l|c|c|l}
\hline 記号 & 反射率 $[-]$ & $\mathrm{H} / \mathrm{D}$ & 反射特性 \\
\hline \hline KL0 & 0.2 & 0.5 & 拡散 $100 \%$ \\
\hline KL1 & 0.2 & 1.0 & 拡散 $100 \%$ \\
\hline KL2 & 0.2 & 2.0 & 拡散 $100 \%$ \\
\hline SL0 & 0.2 & 0.5 & 拡散 $50 \%+$ 再帰 $50 \%$ \\
\hline SL1 & 0.2 & 1.0 & 拡散 $50 \%+$ 再帰 $50 \%$ \\
\hline SL2 & 0.2 & 2.0 & 拡散 $50 \%+$ 再帰 $50 \%$ \\
\hline KH0 & 0.5 & 0.5 & 拡散 $100 \%$ \\
\hline KH1 & 0.5 & 1.0 & 拡散 $100 \%$ \\
\hline KH2 & 0.5 & 2.0 & 拡散 $100 \%$ \\
\hline SH0 & 0.5 & 0.5 & 拡散 $50 \%+$ 再帰 $50 \%$ \\
\hline SH1 & 0.5 & 1.0 & 拡散 $50 \%+$ 再帰 $50 \%$ \\
\hline SH2 & 0.5 & 2.0 & 拡散 $50 \%+$ 再帰 $50 \%$ \\
\hline
\end{tabular}
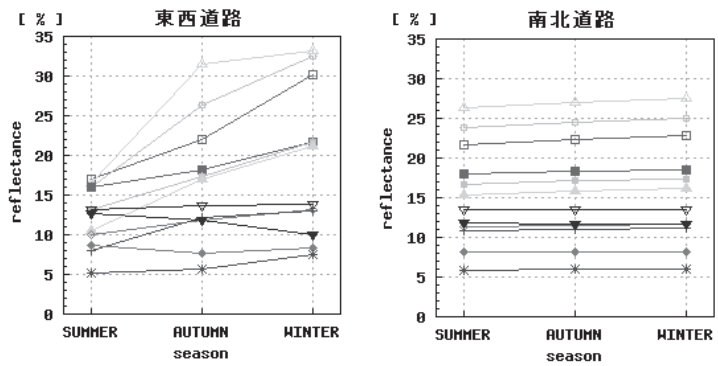

図 11 アスペクト比と再帰反射効果の関係 (キャニオン全体の日射反射率)

表 8 計算条件 (壁面の反射率および反射特性の条件)

\begin{tabular}{c|c|l}
\hline 記号 & H/D & 反射特性 (壁面反射率=0.5[ - ]) \\
\hline \hline $\mathrm{KK} 1 / \mathrm{KK} 2$ & $1.0 / 2.0$ & 拡散 $100 \%$ \\
\hline $\mathrm{KB} 1 / \mathrm{KB} 2$ & $1.0 / 2.0$ & 拡散 $50 \%+$ ビーズ 注 4$) 50 \%$ \\
\hline $\mathrm{BB} 1 / \mathrm{BB} 2$ & $1.0 / 2.0$ & ビーズ $100 \%$ \\
\hline $\mathrm{KS} 1 / \mathrm{KS} 2$ & $1.0 / 2.0$ & 拡散 $50 \%+$ 再帰 $50 \%$ \\
\hline
\end{tabular}

のとき約 $7 \%$ 、2.0のとき約 $11 \%$ 、日射反射率が高くなっている。

(2) 壁面反射率が高く、再帰反射性をもつ場合、南北道路や東西道路 の秋に、アスペクト比が大きい方が日射反射率が高くなり、東 西道路の夏や冬ではほとんど同じ日射反射率になるという他と は異なる傾向がみられる。

\section{5 ガラスビーズの反射指向特性を用いた計算}

前章でモデル化したガラスビーズの反射指向特性を建物壁面に適 用してキャニオン全体の日射反射率を計算し、その特徵を他の反射 特性と比較する。計算条件を表 8 に、計算結果を図 12 に示す。ま た、東西道路および南北道路の秋における、時間帯別のキャニオン 

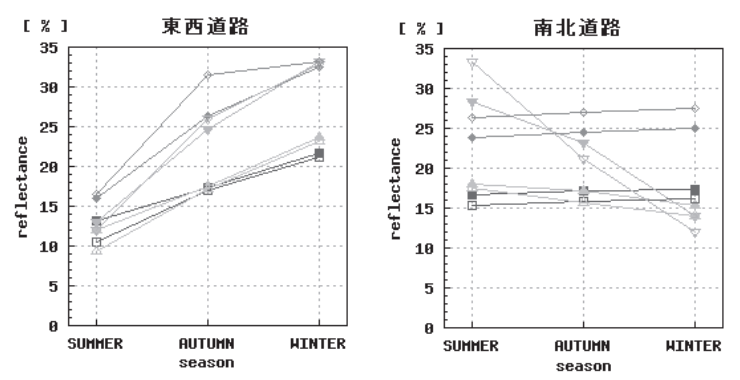

図 12 ガラスビーズの反射特性と他の反射特性の比較 (キャ ニオン全体の日射反射率)
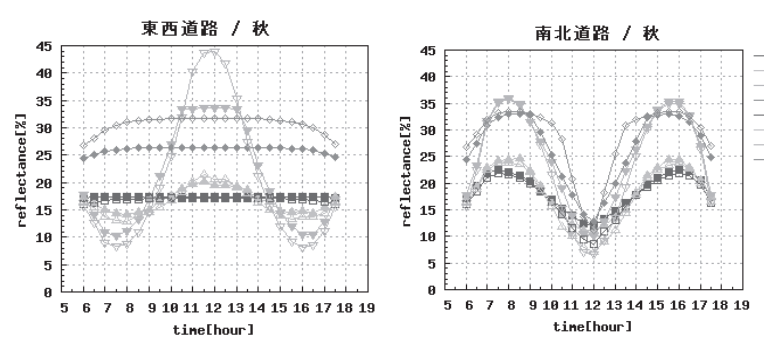

図 13 時間帯別のキャニオン全体の日射反射率

全体の日射反射率の変化を図 13 に示す。

（1）ガラスビーズの反射特性が強い場合（「ビーズ 100\%」）、南北道 路では、夏に日射反射率が高く、冬に低いという他の反射特性 とは異なる傾向を示す。東西道路では再帰反射性に近い傾向を 示し、冬に日射反射率を高くする効果が大きく、夏にはその効 果がほとんどみられない。

(2)「拡散 50\%+ビーズ 50\%」の場合には「拡散 100\%」と非常に似 た傾向を示し、たとえば、東西道路の冬に「ビーズ 100\%」の場 合には「拡散 $100 \%$ に比べて日射反射率が $10 \%$ 以上高くなる のに対し、「拡散 50\%+ビーズ 50\%」ではせいぜい 1 2\% の差 しかない。再帰反射方向とそれ以外の大きくずれた方向とに強 い反射分布をもつという特異な反射特性が影響していると考元 られる。

(3) 時間帯別のキャニオン全体の日射反射率を各条件で比較すると、 ガラスビーズの反射特性が強い場合に、東西道路において、南 中時刻前後に日射反射率が高くなる傾向が顕著である。

4 まとめ

再帰反射材料の反射指向特性を明らかにし、再帰反射も加味した 建物外皮の反射特性が都市の日射反射に及ぼす影響を評価すること を目的として計算を行い、本シミュレーションの設定条件において、 次の結果をえた。

（1）シミュレーションによるガラスビーズ反射指向特性推定では、 屈折率と入射光の向きによる反射の方向分布を計算し、特定の 屈折率のとき再帰反射が大きくなることを示した。実用に向け ては、複数のガラスビーズが並んだ状態を想定し、拡散反射と 組み合わせた反射特性の推定が可能となった。

(2) 都市キャニオンの日射反射率評価では、建物壁面を再帰反射性 とした場合、拡散反射性に比べて、キャニオン全体の日射反射率 は約 5 20\% 高くなった。その効果は、季節や道路の向き、壁 面反射率により異なる。また、ガラスビーズの反射特性も特定 の条件下では同様の効果が期待できる。
謝辞

本研究の一部は、(財) トステム建材産業振興財団、および (公) 大 阪市立大学 都市問題研究の助成 (ともに研究代表 永村一雄) を受け た。記して謝意を表します。

付録 光線追跡シミュレーションの詳細

(1) 壁面の方程式

ガラスビーズが埋め込まれた壁面の方程式は次式で表せる。

$$
x \cos \gamma \cos \left(\frac{\pi}{2}-\phi\right)+y \sin \gamma \cos \left(\frac{\pi}{2}-\phi\right)+z \sin \left(\frac{\pi}{2}-\phi\right)=0
$$

(2) 入射点の決定

半径 $r$ の球面上に一様に分布する点の座標 $\left(a_{x}, a_{y}, a_{z}\right)$ を $[-1,1]$ 上の 一様乱数 $\mathrm{R}_{z}$ と $[0,2 \pi]$ 上の一様乱数 $\mathrm{R}_{\phi}$ を用いて求める。

$$
\left(a_{x}, a_{y}, a_{z}\right)=\left(\cos \left(R_{\phi}\right) \sqrt{r^{2}-R_{z}^{2}}, \sin \left(R_{\phi}\right) \sqrt{r^{2}-R_{z}^{2}}, r R_{z}\right)
$$

ただし、座標 $\left(a_{x}, a_{y}, a_{z}\right)$ は次の入射点 $\mathrm{A}$ の条件 1) 3) を満たさなけ ればならない。

1）ビーズの表面上に存在。

$$
a_{x}^{2}+a_{y}^{2}+a_{z}^{2}=r^{2}
$$

2) 壁面の入射光線側、つまりビーズの露出部分に存在。

$$
a_{x} \cos \gamma \cos \left(\frac{\pi}{2}-\phi\right)+a_{y} \sin \gamma \cos \left(\frac{\pi}{2}-\phi\right)+a_{z} \sin \left(\frac{\pi}{2}-\phi\right)>0
$$

3) 入射光線がビーズ内部を通過せずに到達できる範囲内に存在。

$$
\begin{aligned}
& a_{x}\left(-x_{i_{A}}\right)+a_{y}\left(-y_{i_{A}}\right)+a_{z}\left(-z_{i_{A}}\right)>0 \\
& \boldsymbol{I}_{A}=\left(x_{i_{A}}, y_{i_{A}}, z_{i_{A}}\right)=(\cos \alpha \cos h, \sin \alpha \cos h, \sin h)
\end{aligned}
$$

(3) 入射点での表面反射

入射点 $\mathrm{A}$ に打ける入射角 $\theta_{i}$ 、屈折角 $\theta_{t}$ 抒よびビーズ表面で反射される 光線 注5) の割合 $\rho$ 注 3$)$ を求める。

$$
\begin{aligned}
& \boldsymbol{N}_{A}=\left(x_{n_{A}}, y_{n_{A}}, z_{n_{A}}\right)=\left(-\frac{a_{x}}{r},-\frac{a_{y}}{r},-\frac{a_{z}}{r}\right) \\
& \cos \theta_{i}=\left(-\frac{a_{x}}{r}\right) x_{i_{A}}+\left(-\frac{a_{y}}{r}\right) y_{i_{A}}+\left(-\frac{a_{z}}{r}\right) z_{i_{A}} \\
& \sin \theta_{t}=\frac{\sin \theta_{i}}{n}, \quad \rho=\frac{\rho_{p}+\rho_{s}}{2}, \tau=1.0-\rho
\end{aligned}
$$

(4) 屈折光線の方向および屈折後の到達点

屈折光線 $\boldsymbol{T}$ の向きおよびビーズ背面での反射点 B を求める。

$$
\begin{aligned}
& \boldsymbol{T}=\boldsymbol{N}_{A}\left(\cos \theta_{t}-\frac{1}{n} \cos \theta_{i}\right)+\frac{1}{n} \boldsymbol{I}_{A} \\
& l_{t}=2 r \cos \theta_{t} \\
& \left(b_{x}, b_{y}, b_{z}\right)=\left(l_{t} x_{t}+a_{x}, l_{t} y_{t}+a_{y}, l_{t} z_{t}+a_{z}\right)
\end{aligned}
$$

ただし、座標 $\left(b_{x}, b_{y}, b_{z}\right)$ は次の反射点 B の条件を満たさなければなら ない注 5)。

$$
b_{x} \cos \gamma \cos \left(\frac{\pi}{2}-\phi\right)+b_{y} \sin \gamma \cos \left(\frac{\pi}{2}-\phi\right)+b_{z} \sin \left(\frac{\pi}{2}-\phi\right)<0
$$

(5) 反射光線の方向および反射後の到達点

反射光線 $\boldsymbol{R}$ の向きおよびビーズ表面での出射点 C を求める。

$$
\begin{aligned}
& \boldsymbol{I}_{B}\left(x_{i_{B}}, y_{i_{B}}, z_{i_{B}}\right)=\boldsymbol{T}\left(x_{t}, y_{t}, z_{t}\right) \\
& \boldsymbol{N}_{B}=\left(x_{n_{B}}, y_{n_{B}}, z_{n_{B}}\right)=\left(\frac{b_{x}}{r}, \frac{b_{y}}{r}, \frac{b_{z}}{r}\right) \\
& \boldsymbol{R}=-2 \boldsymbol{N}_{B} \cos \theta_{t}+\boldsymbol{I}_{B} \\
& \left(c_{x}, c_{y}, c_{z}\right)=\left(l_{t} x_{r}+b_{x}, l_{t} y_{r}+b_{y}, l_{t} z_{r}+b_{z}\right)
\end{aligned}
$$

ただし、座標 $\left(c_{x}, c_{y}, c_{z}\right)$ は次の出射点 $\mathrm{C}$ の条件式を満たさなければな らない。次式を満たさない場合、光線はビーズの外に出射せず、ビーズ 内部で反射を繰り返す注 6)。

$$
c_{x} \cos \gamma \cos \left(\frac{\pi}{2}-\phi\right)+c_{y} \sin \gamma \cos \left(\frac{\pi}{2}-\phi\right)+c_{z} \sin \left(\frac{\pi}{2}-\phi\right)>0
$$


(6) 出射光線の方向

出射光線 $\boldsymbol{E}$ の向きを求める 注 5)。

$$
\begin{aligned}
& \boldsymbol{I}_{C}\left(x_{i_{C}}, y_{i_{C}}, z_{i_{C}}\right)=\boldsymbol{T}\left(x_{r}, y_{r}, z_{r}\right) \\
& \boldsymbol{N}_{C}=\left(x_{n_{C}}, y_{n_{C}}, z_{n_{C}}\right)=\left(\frac{c_{x}}{r}, \frac{c_{y}}{r}, \frac{c_{z}}{r}\right) \\
& \boldsymbol{E}=\boldsymbol{N}_{C}\left(\cos \theta_{i}-n \cos \theta_{t}\right)+n \boldsymbol{I}_{C}
\end{aligned}
$$

(7) 入射光線と出射光線とのずれの角度

入射光線 $\boldsymbol{I}_{A}$ と出射光線 $\boldsymbol{E}$ のずれの角 $\eta$ およびその方位角方向成分 $\eta_{y}$ と高度方向成分 $\eta_{z}$ を求める。

$$
\begin{aligned}
& \cos \eta=-\left(x_{i_{A}} x_{e}+y_{i_{A}} y_{e}+z_{i_{A}} z_{e}\right) \quad\left(0^{\circ} \leq \eta \leq 180^{\circ}\right) \\
& \boldsymbol{E}=\left(x_{e}, y_{e}, z_{e}\right)=\left(\cos \theta_{e y} \cos \theta_{e z}, \sin \theta_{e y} \cos \theta_{e z}, \sin \theta_{e z}\right) \\
& \eta_{y}=\theta_{e y}-\alpha \quad\left(-180^{\circ} \leq \eta_{y} \leq 180^{\circ}\right) \\
& \eta_{z}=\theta_{e z}-h \quad\left(-180^{\circ} \leq \eta_{y} \leq 180^{\circ}\right)
\end{aligned}
$$

注

注 1) 壁面に対する光の入射角 $i$ とは、壁面の向きと入射光の向きによって決 まり、次式で与えられる。

$$
\cos i=\cos \phi \cdot \sin h+\sin \phi \cdot \cos h \cdot \cos (\alpha-\gamma)
$$

注 2）壁面の反射指向特性として、拡散反射と再帰反射を $50 \%$ ずつの割合で 用いることを示す。

注 3) ビーズ表面の反射率および鏡面反射の反射率は、 $\mathrm{P}$ 偏光と $\mathrm{S}$ 偏光のガ ラス表面での反射率 $\rho_{p}, \rho_{s}$ の平均值を用いた。鏡面反射については、 $n=1.93$ と仮定した。 $\rho_{p}$ おょび $\rho_{s}$ は次式で求める。

$$
\rho_{p}=\left(\frac{\cos \theta_{t}-n \cdot \cos \theta_{i}}{\cos \theta_{t}+n \cdot \cos \theta_{i}}\right)^{2} \quad, \quad \rho_{s}=\left(\frac{\cos \theta_{i}-n \cdot \cos \theta_{t}}{\cos \theta_{i}+n \cdot \cos \theta_{t}}\right)^{2}
$$

注 4) 予備計算で、ガラスビーズの屈折率による反射指向特性の違いは、キャ ニオン全体の日射反射率にほとんど影響のないことが示された。よっ て、本計算では屈折率 $n=1.93$ を採用した。

注 5) 計算の中で、出射本数に含めない光線の模式図を図 14 に示す。ただ し、(1)は「反射」、(2)・(3)「吸収」として报う。

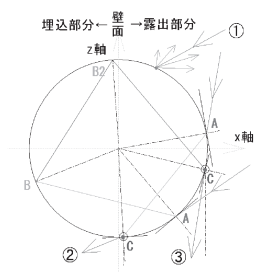

(1) 入射点の表面で反射

(2) 反射点 $\mathrm{B}$ がビーズ露出部分にあり、点 $\mathrm{B}$ から壁面に向かって出射

(3) 出射点 C から壁面に向かって出射

図 14 出射本数に含めない光線の模式図

注 6) 本計算では、ビーズ背面での反射率を $1.0[$ - ] と仮定したが、実際には 埋込部分の塗料等の反射率を考慮する必要がある。

\section{参考文献}

1) 気像庁：ヒートアイランド監視報告 (平成 19 年冬・夏一関東・近畿地 方), 2008.5

2) 藤本哲夫, 岡田朋和, 近藤靖史 : 高反射塗料の日射反射性能に関する研 究, 日本建築学会環境系論文集, No.601, pp.35-41, 2006.3

3) 近藤靖史, 小笠原岳, 大木泰祐, 有働邦広 : 建物屋根面の日射反射性 能向上によるヒートアイランド緩和効果, 日本建築学会環境系論文集, Vol.73, No.629, pp.923-929, 2008.7

4) 今田寬典, 門田博和, 児島武男：区画線に添加するガラスビーズの再帰 反射特性に関する三次元解析, 土木学会論文集, No.413 IV-12, 1990.1

5) 西川 進：特開 2003-268730 : 路面表示用反射材㧍よびその製法, 日本 国特許庁公開特許広報 (A), 2003.9.25

6) 日本規格協会：JIS Z 9117 保安用反射シート及びテープの試験方法, 1984

7) 中大䆶千晶, 梅干野昆, 浅輪貴史, 深澤英之 : 屋外熱シミュレーション に㧍ける建築材料の日射反射指向特性を考慮した放射伝熱計算モデルの 導入, 日本建築学会環境系論文集, Vol.73, No.625, pp.275-282, 2008.3
8) 酒井英樹, 永村一雄, 井川憲男 : 再帰反射材の照り返し抑制効果, 日本 建築学会構造系論文集, Vol.73, No.630, pp.1239-1244, 2008.8

9) 酒井英樹, 小林春奈, 永村一雄, 井川憲男 : 屋外測定による再帰反射材 の日射に対する再帰反射率推定, 日本建築学会構造系論文集, Vol.73, No.632, pp.1713-1718, 2008.10

10）西岡真稔, 井上 智, 酒井憲司 : 幾何光学的分析に基づく再帰反射性能算 定法一再帰反射を用いた日射反射体の性能評価一, 日本建築学会環境系 論文集, Vol.73, No.633, pp.1249-1254, 2008.11

11) 井野英二：高反射および高屈折率ガラスビーズ, 科学と工業, Vol.57, No.9, pp.357-361, 1983

12) 谷口 博, Wen-Jei Yang, 工藤一彦, 黒田明慈, 持田明野: パソコン活用 のモンテカルロ法による放射伝熱解析, コロナ社, pp.48-58, 1994.1

13) 湊 崇徳, 西岡真稔, 鍋島美奈子, 中尾正喜 : 都市キャニオンにおける高 反射面の配置に関する基礎検討, 日本建築学会大会学術講演梗概集・環 境 I, pp.627-628, 2005.9

（2009年 3 月 6 日原稿受理，2009年 5 月 26 日採用決定） 